\title{
Kiből lettek és kivé válnak a 21. század gyermekei?
}

\section{BENYUSZ MÁRTA ${ }^{1}$}

A gyermek mint jogalany kiemelt értékessége a hétköznapi párbeszédek szintjén alapvetésnek és világnézetektől függetlennek tünik. A kérdés mélyére tekintve ugyanakkor egyértelmüvé válik, hogy nagyon gyakran a kiemelt értékességet nem a gyermekek, hanem a büvös 18. életévet átlépett felnöttek perspektívájából határozzuk meg, és a gyermekek jogai mind mikro- (család, iskola), mind makro- (nemzeti és nemzetközi jogalkotó) szinten relativizálódnak. Ahhoz, hogy a gyermek és a gyermekkora hatékony védelmet kapjon, szükségszerü a gyermek megértése és "gyermekjogi szemüvegen” keresztül való szemlélése. Ehhez a megértéshez igyekszem közelebb kerülni a tanulmányban azzal, hogy a történelem kezdetétöl áttekintem, miként gondolkodott a múlt embere gyermekéröl, a gyermek helyéről a társadalomban, a szülö és a gyermek kapcsolatáról, és ez miként vezetett el a 21. század bizonytalanságaihoz.

Kulcsszavak: gyermek, gyermekjogok, gyermekkor, emberi méltóság, család, élethez való jog, védelemhez való jog, kereszténység, nemzetközi jog

\section{Evolution and Perspectives of the $21^{\text {st }}$ Century Children}

On the level of an everyday dialogue the paramount value of the child as a legal entity seems to be fundamental and free of ideologies. However, looking the issue in depth it becomes clear that very often this value is determined not from the perspective of children but from the point of view of adults, which causes the rights of children both on micro (family, school) and on macro (national and international legislator) level to be relativised. In order to effectively protect children and their childhood it is essential to deeply understand them and to wear "child rights glasses". In this study, I try to get closer to this understanding by reviewing from the beginning of history how the man of the past thought about the child, the child's place in society, the parent-child relationship and how this led to the uncertainties of the $21^{\text {st }}$ century.

Keywords: child, children's rights, childhood, human dignity, family, right to life, right to protection, Christianity, international law

1 Főosztályvezető, Mádl Ferenc Összehasonlító Jogi Intézet, Nemzetközi és Uniós Jogi Kutatási Főosztály; doktori hallgató, Pázmány Péter Katolikus Egyetem Jogés Âllamtudományi Kar, e-mail: marta.benyusz@mfi.gov.hu 


\section{Alapvetések}

Az ENSZ Gyermekjogi Egyezményének 1. cikke rögzíti, hogy „az Egyezmény vonatkozásában gyermek az a személy, aki tizennyolcadik életévét nem töltötte be, kivéve, ha a reá alkalmazandó jogszabályok értelmében nagykorúságát már korábban eléri [szerzői kiemelés]". A ma hatályos magyar jogszabályok - az Egyezmény rendelkezéseivel összhangban - szintén a 18 éves korhatárt tekintik zsinórmértéknek, és a gyermeket élve születésétöl, amennyiben élve születik fogamzásától $l^{2}$ kezdve 18 éves koráig speciális védelemben részesítik. A Büntető Törvénykönyv 12 éves korhoz köti a beleegyezéses szexuális kapcsolat létesítését, a Polgári Törvénykönyv megengedi, hogy egy 16 éves gyermek házasságot kössön, az azonban kizárt, hogy ünneplésként alkohol tartalmú itallal koccintson a vendégekkel, vagy nászajándék reményében legálisan kitöltsön egy lottószelvényt. Kizárólag a jogszabályi rendelkezéseknek e szűk szegmensét tekintve rögtön érezhető egyfajta nehezen megfogható ellentmondásosság, amely egyértelmủen alátámasztja a gyerekkor, a gyermeki lét természetének speciális voltát, és természetszerủen felteszi azt a kérdést, hogy kit is tekintünk tehát gyermeknek, és kinek tekintjük a gyermeket? Ahhoz, hogy a válaszhoz közelítsünk, haszontalan a jogszabályok rendelkezéseiből kiindulni, azokon jóval túltekintve kell keresni a támpontokat, amelyek közelebb visznek ahhoz, hogy valóban megértsük az emberi élet kezdeti szakaszának sérülékenységét. A minél mélyebb, társadalmi, erkölcsi, filozófiai és jogfilozófiai síkon történő megismerés és megértés segítheti azt, hogy a valódi védelem ${ }^{3}$ mind mikro- (családok), mind pedig makro- (jogalkotó, jogalkalmazó) szinten megszülethessen. A válaszhoz való közelebb kerülést a megismerés időbeli kereteinek kiszélesítése is segítheti, hiszen az emberről és gyermekéről, a gyermek helyéről a társadalomban, a szülő és a gyermek kapcsolatáról az évszázadok, sőt évezredek alatt nagyon eltérő módon gondolkodtak.

Jelen tanulmány a választ arra a kérdésre, hogy kinek tekintjük a gyermeket, elsősorban az időbeli megismerés kereteiből kiindulva keresi, és arra vállalkozik, hogy a történelem kezdetétöl áttekintse a gyermek helyét a társadalomban, családban és ehhez mérten rámutasson arra a fejlődési útra, amelyen a gyermekekről, a gyermekek jövőjéről és jogairól alkotott kép keresztülment, eljutva a 21. század bizonytalanságaihoz.

Ez az időbeli megismerés egyrészt megpróbálja feltárni a tényleges valóságot, amelyet egy-egy történelmi korszak a realitások talaján jelentett a gyermekek tömegei számára. Másrészt a kor egy-egy meghatározó filozófusának, gyakran a valóságnak csak egy-egy szeletét, illetve a „kiváltságos” valóságot tükröző gondolatain keresztül, bejárja azt az ívet, amellyel eljutunk a gyermekjogok mai nemzetközi jogi szabályozottságához és ahhoz az ambivalenciához, amely a gyermek kiemelkedő értékként

2 A Ptk. 2:2\$-a szerint a jogképesség az embert, ha élve születik, fogamzásának időpontjától illeti meg.

3 A védelemhez való jog a gyermekek egyik primer joga. 
való kezelése és jogaik gyakori és súlyos sérülése között húzódik. ${ }^{4}$ A gyermeki lét érzékenységéről, specialitásáról, egyéni és közösségi (intézményi), gyakorlati és elvi szinten is kizárólag multidiszciplináris keretek között érdemes beszélni, így a tanulmány kísérletet tesz arra, hogy megpróbálja a jogi aspektusokat egybegyúrni azokkal a nevelési, neveléslélektani, pszichológiai lépcsőfokokkal is, amelyek elvitathatatlanul hozzájárultak a gyermekkép fejlődéséhez, és ezeket összességében értékelve elemezni a gyermek értékességét, személyi voltát az egyes korokban.

\section{Az őskor gyermekei}

\subsection{Társadalmi alapeszme}

A biológiai értelemben vett mai ember (Homo sapiens sapiens) körülbelül 90-160 ezer évvel ezelőtt jelent meg Kelet-Afrikában. ${ }^{6}$ Az ősközzösségeket a vadászó-gyüjtögető életmód jellemezte, ahol az ember a természetbe tagolódva erősen összehangolt cselekvési szabályok és normák által működő közösségekben létezett. ${ }^{7}$

\subsection{Gyermekkép}

A 20. század elején még éltek olyan népcsoportok, amelyek szinte érintetlenül megőrizték az ősközösségi életformát, ${ }^{8}$ ennek köszönhetően viszonylag biztos következtetések vonhatók le arra vonatkozóan, hogy ki is volt az „ősember” gyermeke. A gyermekek a közösség egészének felügyelete és gondozása alatt nőttek föl, a gondoskodás, nevelés eredményességén múlott ugyanis a csoport túlélése. ${ }^{9}$ Ebben a kontextusban tehát a gyermek a túlélés és így a jövő záloga volt. Bár gyermekkorról a mai értelemben véve nem beszélhetünk, ${ }^{10}$ a gyermek tanítására alkalmazott játékos módszerek és az erkölcsi nevelés során, a testi fenyítéssel szemben előnyben részesített és elsődlegesen alkalmazott következményalapú nevelés ${ }^{11}$ alátámasztják azt, hogy az ősközösségek embere értette a gyermekkor sajátos természetét és speciális igényeit. Ezt támasztja alá a beavatás intézménye is, amely mérföldkő volt, és a felnőtt életbe való testi és lelki bekapcsolódást szimbolizálta. A gyermekek számára a család jelentette

$4 \quad$ Frivaldszky János (szerk.): A jogfilozófia alapvető kérdései és elemei. Budapest, Szent István Társulat, 2013. 98.

5 Jelen tanulmányban a társadalmi alapeszme vázlatpontok alatt a teljesség igénye nélkül mutatjuk be az adott kor azon sajátosságait, amelyek kiemelése szükséges a kapcsolódó gyermek(kép) megértéséhez.

6 Lásd: www.britannica.com/topic/Homo-sapiens-sapiens

7 Pukánszky Béla - Németh András: Neveléstörténet. Budapest, Nemzeti Tankönyvkiadó, 1996.

8 Pukánszky-Németh (1996): i. m. 1.

9 Berzsenyi Emese: A társadalmi gondoskodás és tanítás történelmi előképei. Iskolakultúra, 25. (2015), 9. 100-112.

10 Philippe Ariès: L'enfant et la vie familiale sous l'Ancien Régime. Revue française de sociologie, (1960), 1-4. 486-488.

11 Pukánszky-Németh (1996): i. m. 3. 
az életet, a szülői, illetve a közösségi szeretet pedig a biztonságot. ${ }^{12}$ Érdemes rátekinteni erre a gyermekképre a szereteten és gyermeki biztonságon alapuló kötődő nevelés aspektusából, az ősember tudattalanul megérezte a biztonság és a szeretet iránti mély gyermeki igényt, és ha észrevétlenül átcseppent volna a 21. századba, a gyermekekkel szembeni erőszak „zéró toleranciájának” elve egészen biztosan nem hatott volna olyan idegenül, mint az antikvitás, a középkor, vagy akár a 19. század gyermekének.

\section{Az ókor gyermekei}

\subsection{Az ókori kelet (Mezopotámia, Egyiptom)}

\subsubsection{Társadalmi alapeszme}

Az ókori keleti rabszolgatartó birodalmak igen kedvező természeti körülmények között alakultak meg, így stabil társadalmi fejlődés vette kezdetét. ${ }^{13}$ Megjelent az irásbeliség, a társadalmi berendezkedésre, és benne az ember egyéni és közösségi helyére megalapozott írásbeli források utalnak. Ezek a források azonban elsősorban a kezdetleges „intézményi” megközelítésre engednek következtetni, amely az egyre hierarchikusabbá váló és az isten(ek) felé forduló társadalmakban elhomályosítja az egyén szerepét, az egyén személyes megélését, és a közösség jóllétére és túlélésére helyezi a hangsúlyt.

\subsubsection{Gyermekkép}

Az ókori keleti kultúrák a gyermeket nagy becsben tartották $\cdot{ }^{14} \mathrm{~A}$ korai Mezopotámiában a városállamok jövője függött a gyermekek műveltségétől. A sumér kultúrában, ellentétben az ősközösségi társadalmakkal, a testi fenyítést a „gyermeknevelés” fontos és elfogadott eszközeként alkalmazták. Hammurápi törvényei [309-314.\$] kezdetleges formában tartalmaztak a magzat védelmére utaló rendelkezéseket. ${ }^{15} \mathrm{Az}$ ókori Egyiptomban tiltották a csecsemőgyilkosságot, ${ }^{16}$ elismerték a gyermek sebezhetőségét és kiszolgáltatottságát. A gyermeket nem pólyázták, hároméves korukig szoptatták, ${ }^{17}$ ami arra enged következtetni, hogy a gyermekekkel az életük kezdeti szakaszában sokat foglalkoztak. A nevelés legfontosabb célja az istentől származó örökérvényủ igazság megismertetése volt. ${ }^{18}$ Ezzel együtt a gyermek fontossága az ókori keleti társadalmakban igen ellentmondásos, a gyermeki lét és a felnőtt lét közötti határok kizárólag

12 Pukánszky-Németh (1996): i. m. 3.

13 Pukánszky-Németh (1996): i. m. 3.

14 Albert Gábor: A nevelés történeti és elméleti alapjai. Kaposvár, Kaposvári Egyetem, 2011.

15 Hammurabi törvényei. (ford. dr. Kmoskó Mihály), Kolozsvár, Az Erdélyi Múzeum-Egyesület Jogés Társadalomtudományi Szakosztálya, 1911.

16 Albert (2011): i. m.

17 Pukánszky-Németh (1996): i. m.

18 Pukánszky-Németh (1996): i. m. 3. 
a gyermek biológiai érése függvényében alakultak. ${ }^{19}$ Bár a gyermeket becsben tartották, mégsem volt igazi érték. ${ }^{20}$ Következésképpen a lelki aspektusok és a gyermeki léthez kapcsolódó sajátosságok tiszteletben tartásának és elismerésének, a vele való törődésnek elsődleges célja a túlélés, a gyermek mihamarabbi (akár idő előtti) felnőtté válása, és nem önmagában a gyermek mint személy és gyermekkorának védelme.

\subsection{A görög kultúra}

\subsubsection{Spárta}

\subsubsection{Társadalmi alapeszme}

Spárta katonai állam volt, ahol a hatalom a katonai arisztokrácia kezében összpontosult. A rabszolgák száma jóval meghaladta a szabad spártaiak számát, ezért szükségszerủ volt az állandó katonai készenlét. A stabilitás megőrzése érdekében és a közösség érdekeinek védelme céljából a polisz vezetői az állampolgárok legszemélyesebb magánügyeibe is beleszólhattak. ${ }^{21}$

\subsubsection{Gyermekkép}

Spártában a gyermek elsősorban a jövő katonája volt. A nevelés legfőbb céljának az állandó harci készenlétre való felkészítést, a jó katona kiképzését tartották. ${ }^{22} \mathrm{Az}$ egészséges, jó katonai „alapanyag” létkérdés volt, ezért a polisz vezetése meghatározta a házasságkötés feltételeit (például tiltott volt a családon belüli házasság), az újszülöttről nem a saját szülei rendelkeztek, hanem az állam. A polisz vezetői szerint életképtelennek minösitett csecsemőt letaszították a Taigetoszról, a csecsemőgyilkosság elfogadott, sőt ebben a formában kívánatos volt. A gyermekeket az egyiptomiakhoz hasonlóan nem pólyázták be, ${ }^{23}$ ezzel biztosítva a szabad testi fejlődést, ugyanakkor korukhoz mérten, folyamatosan edzették, keményítették őket mind testileg, mind érzelmileg. ${ }^{24} \mathrm{~A}$ rideg, elsősorban a fizikai kvalitásokra koncentráló katonai nevelést a fiúgyerekek hétéves korukban kezdték. Ez a fajta szemléletmód jellemezte a lányok nevelését is, hiszen az ő feladatuk volt, hogy egészséges fiúgyermekeknek adjanak életet „Spárta dicsőségére”.

A gyermeki lét sajátosságait, önálló személy voltát érzékenyen figyelembe vevő megközelítésről Spártában gyakorlatilag egyáltalán nem beszélhetünk. A gyermek -

19 Portik Erzsébet Edit: Gyermeknevelés az ókori társadalmakban. Magiszter, 12. (2012), 2. 73.

20 Vajda Zsuzsanna - Pukánszky Béla: A gyermekkor története. Szöveggyüjtemény. Budapest, Eötvös József Kiadó, 1988. 13.

21 Pukánszky-Németh (1996): i. m.

22 Portik (2012): i. m. 75.

23 Pukánszky-Németh (1996): i. m.

24. A spártai kisgyermekeknek tiltották a sírást. Albert (2011): i. m.

25 Portik (2012): i. m. 75. 
hasonlóan az ősközösségek vagy az ókori kelet gyermekéhez - a túlélés záloga volt, ugyanakkor Spártában már - az ősközösségekkel erősen ellentétesen - nem jelentkezik az a természetes, ösztönszerü odafordulás a gyermekhez, amely tudat alatt is figyelembe veszi a gyermekkort, hanem a gyermeki lét egyfajta szükséges rosszként előzte meg az erős felnőtt, katonai létformát.

\subsubsection{Athén}

\subsubsection{Társadalmi alapeszme}

Athénban, Spártával ellentétben jóval nagyobb számban éltek szabadok, ${ }^{26}$ a szabadoknak nem kellett - spártai módra - állandó harci készültségben élniük, ${ }^{27}$ ami az athéni társadalom „könnyedebb” életformáját tette lehetővé. Periklész ${ }^{28}$ athéni államférfi így fogalmazott:

„S ha mi inkább könnyedebb életmóddal, mint fáradságos gyakorlatokkal, és nem a törvények által belénk oltott, hanem elsősorban velünk született bátorsággal készülünk a veszedelmek leküzdésére, ez azzal az előnnyel is jár, hogy nem ízleljük meg már előre a még csak közelgő megpróbáltatásokat, ha viszont már bennük vagyunk, nem tanúsítunk kisebb hősiességet azoknál, akiknek egész élete fáradozásban telik." ${ }^{29}$

\subsubsection{Gyermekkép}

A periklészi gondolatot az athéni céltudatos gyermeknevelés a hétköznapok színterébe emelte. A „veleszületett bátorság” generális zsinórmértéke volt a harmonikus ember, aki bátorságban felveszi a versenyt a harcos spártaiakkal, ugyanakkor a harmóniából, „könnyedségből” fakadó értelme, nyitottsága, erkölcsi érzékének fejlettsége, a szépség iránti fogékonysága ${ }^{30}$ értékesebbé is teszi.

Az ókori athéniak értették a gyermekeik alapvető szükségleteit, életkori sajátosságait, játékszükségletüket, szeretetigényüket, ${ }^{31}$ azaz érezték a gyerekkor specialitását, filozófusaiknak köszönhetően fejlődéslélektani ismeretekkel is rendelkeztek, így nemcsak általánosan a gyermek és a gyermekkor sajátosságait látták, hanem felismerték gyermekeik közötti egyéni különbségeket is.

26 Athénban a polisz társadalmát az arisztokrácia, a démosz (nép) és a rabszolgák alkották, kezdetben az államforma az arisztokratikus köztársaság, majd a Kr. e. 7. századtól a demokrácia volt.

27 Pukánszky-Németh (1996): i. m.

28 Az athéni demokrácia Periklész idején élte fénykorát.

29 Pukánszky-Németh (1996): i. m.

30 Pukánszky-Németh (1996): i. m.

31 Portik (2012): i. m. 76-77. 
Szókratész szerint „minden dolog mértéke az ember”,32 aki megismer, gondolkodik és cselekszik. A megismerés, gondolkodás, cselekvés pedig nem pusztán a külvilág, hanem önmaga felé is irányul. Az etikai intellektualizmust képviselte, amelynek lényege, hogy aki „tudja” a jót, az törekszik is annak megvalósítására. Ez a tudás pedig nem szabad, hogy csupán kiválasztott emberek privilégiuma legyen, a nevelés által törekedni kell a tudás gyermek felé történő közvetítésére. Szókratész tehát erősen hitt az erény taníthatóságában, ${ }^{33}$ azaz a gyermek formálhatóságában. Az első olyan filozófus, aki a gyermekfejlődést ( 21 éves életkorig) különböző szakaszokra osztotta, ${ }^{34}$ az egyes fejlődési szakaszokhoz kapcsolódó speciális jellemvonások, életkori sajátosságok mentén. Szókratész szerint a nevelés végére, 21 éves korukra az ifjak megértek a házasságra, amely így egyfajta nagykorúság elérését is jelentette. Ez a megközelítés azonban csupán a filozófia színterén létező valóság volt, a társadalom és az állam mủködését szabályozó törvények nem tükröztek ilyen mértékü differenciált érzékenységet a gyermekkor és annak sajátosságai iránt. Mindezzel azonban Szókratész előhírnöke volt annak, hogy az emberi élet kezdeti szakasza nemcsak hogy elismerést és sajátos odafordulást, speciális válaszokat igényel mind jogi (szabályozási), mind nevelési, neveléslélektani szempontból, hanem ennek a kezdeti szakasznak a tovább differenciálása és ennek mentén differenciált szabályozása is szükséges.

Platón gyermekképére, véleményére a gyermek életének kezdetéről és jövőjéről leginkább az Állam és a Törvények címủ műveiből lehet következtetni. Az Államban Platón az abortusz mellett foglal állást, amely szerinte egy természetes eljárás, különösen akkor, ha a férfi a saját lányával, anyjával, esetleg unokájával folytatott szexuális viszonyt, vagy, ha a nő fiával, apjával és egyéb vér szerinti rokonukkal hál, aminek terhesség lesz az eredménye. ${ }^{35}$ Azaz Platón felfogásában a potenciális emberré válás lehetôsége egyáltalán nem számitott, semmiféle erkölcsi ellenvetést nem fogalmaz meg sem az abortuszról, sem a csecsemőgyilkosságról. ${ }^{36} \mathrm{Ez}$ a véleménye egyébként ellentétben áll Hippokratész, ókori orvos álláspontjával, ${ }^{37}$ aki szerint az abortusz becstelen, ugyanis mindig veszéllyel és erőszakkal jár. ${ }^{38}$

Bár Platón a magzati korú gyermeket és így az életének legsérülékenyebb szakaszát szélsőséges módon, erkölcsi fenntartások nélkül negligálta, az élve született, egészséges

32 Prótagoraszi tétel, amelyet Szókratésszel együtt a szofisták is hangoztattak.

33 Pukánszky-Németh (1996): i. m.

34 Az első szakasz a családi nevelés ideje, a második szakasz pedig a tanulás kezdete. Grammatikát, rajzot és testgyakorlást sürget. A harmadik szakasz az ifuúkor kezdete, amely megköveteli az alkotmány szellemében való nevelést. Az ifjak nevelése 21. életévük után fejeződik be, amikor megérettek a házasságra.

35 Gradvohl Edina: Az abortusz megítélése az antik világban. Müvelődés-, Tudományés Orvostörténeti Folyóirat, 6. (2015), 11. 3-4.

36 Kiemelendő az úgynevezett amphidromia intézménye, amelynek során a befogadás aktusaként egy speciális szertartás keretében vezették be a gyermeket a családba, előtte azonban büntetlenül ki lehetett tenni az újszülöttet.

37 Hippokratész egyetlen esetben tartja elfogadhatónak az abortuszt, amikor az anya élete veszélyben forog, és az abortuszt úgynevezett terápiás céllal alkalmazzák.

38 Gradvohl (2015): i. m. 2. 
gyermek fontos volt számára, érdekelték ${ }^{39}$ a gyermekkor sajátosságai. Úgy vélte, hogy alakítani, formálni, tanítani kell őket, hiszen tőlük függ a jövő, az állam jóléte. Platón a Törvényekben - Szókratészhoz hasonlóan, azonban eltérő logikával - a gyermek fejlődését szakaszokra bontotta. ${ }^{40}$ Platón szerint a gyermeki lélek formálható, fontos, hogy a kicsiket a lehető legkevesebb fájdalom érje, a gyermeknek szüksége van a játékra, 6 éves kortól a gyermekeket nemek szerint el kell különíteni. Platón szerint a személyiség, egyéniség lényege kisgyermekkorban alakul ki.

Arisztotelész az abortuszról és a csecsemőgyilkosságról Platónhoz hasonlóan vélekedett. ${ }^{41}$ Politika című mủvében leírja, hogy a „korcs szülöttet” nem szabad felnevelni, és erről a szabályozásnak gondoskodnia kell. Az abortuszt pedig mindaddig megengedettnek és erkölcsileg is (születésszabályozási célból) elfogadottnak tartotta, amíg a méhmagzat meg nem mozdult. Ugyanebben a müvében Arisztotelész - a platóni megközelítést továbbgondolva - lefektette a gyermeki lét fejlődési szakaszait is. ${ }^{42}$ Arisztotelész a Nikhomakhoszi ethikában az emberi élet céljaként a boldogságot jelöli. A boldogság pedig erényességet jelent, ezért az élet kezdeti szakaszának, a gyermeknevelésnek célja, hogy a gyermekek erényes polgárokká váljanak.

\subsection{Római jog}

\subsubsection{Társadalmi alapeszme}

A köztársasági kor végére Róma szellemi életében kialakult egy, a további évszázadok során maradandónak bizonyuló, az ideális társadalom alapkövét biztosító, „,ómai családra" vonatkozó eszménykép, amely szerint a római házasság tartós, gyermekekben gazdag, monogám kapcsolat, amellyel a római polgár nemcsak a természet parancsának, de a „res publica”, az állam iránti kötelezettségeinek is eleget tesz. ${ }^{43}$ A házasság létének célja és értelme a liberorum quaerundorum causa, a gyermekek iránti vágy és a leszármazottak irányában megnyilvánuló gondoskodás ösztöne, amelyet a római eszménykép szerint a természet oltott minden élőlénybe, így az emberbe is. ${ }^{44} \mathrm{~A}$ családi élet természeti vetülete mellett legalább annyira lényeges annak társadalmi vetülete is: a házasság intézménye egyben a civilizált állami élet talpköve is. ${ }^{45} \mathrm{~A}$ házasságból származó törvényes utódok pedig a család és az állami élet legfontosabb értékeinek továbbvivői is, így a házasságban élő és a házasságban gyermekeket a világra hozó em-

39 Pukánszky-Németh (1996): i. m.

40 Platón: Törvények. (789e, 792a, 789e, 792b, 792e, 793e, 794a, b,793e, 794c, d, 794d, 795e, 794d).

41 Gradvohl (2015): i. m. 4.

42 Pukánszky-Németh (1996): i. m. 1336b) 7-serdülőkorig: folytasson tanulmányokat.

43 Péter Orsolya Márta: „Alimenta”. A családpolitika és a gyermekes családoknak nyújtott állami támogatások előképei a klasszikus Rómában. Publicationes Universitatis Miskolcinensis. Sectio Juridica et Politica 23/1. (2005), 91-124.

44 Péter (2005): i. m.

45 Péter (2005): i. m. 
ber e cselekedetével az állam iránt fennálló legfontosabb kötelességét is gyakorolja. ${ }^{46}$ A római társadalom erősen patriarchális volt.

\subsubsection{Gyermekkép}

A „római család” eszményképéből kisejlik az a különbségtétel, amelyet a házasságon belül és a házasságon kívül született gyermekek között tettek az ókori Rómában. $\mathrm{Az}$ alapvetően patriarchális társadalomban ugyanígy erős különbség volt a lány és a fiúgyermek között is. ${ }^{47} \mathrm{~A}$ rómaiak - hasonlóan a görögökhöz - érezték a gyermekkor és különösen az első időszak érzékenyégét. ${ }^{48} \mathrm{~A}$ római nevelés célja, hogy a gyermek jó emberré (vir bonus) váljon, aki majd köztisztviselőként Róma örök dicsőségét szolgálhatja ${ }^{49}$ - ellentétben az antik görög megközelítéssel, ahol a műveltség önmagában volt cél. A rómaiak alapvetően gazdagították a görögök által átvett gyermekképet, ${ }^{50}$ megközelítésük mégis számos ambivalenciát hordoz a gyermek valódi értékessége kapcsán. A pater familias, vagyis a családapa, a „római család” feje a gyermekei felett a patria potestas (atyai hatalom) joggal rendelkezett. ${ }^{51} \mathrm{~A}$ családfö birtokolta a következőket is: a ius vitae ac necis (a gyermek élete és halála fölötti rendelkezés) és ius exponendi (a gyermekkitétel joga)..$^{52}$ Nagyon gyakori volt a gyermek - különösen a lánygyermekek - kitétele, az abortusz és a születésszabályozás. ${ }^{53}$ Az ókori Rómában az abortusz nem számított bünnek, nem volt erkölcstelen, csak akkor büntették, ha az apa a férj jogait sértette, azonban a magzat életének védelmét nem tartották fontosnak. ${ }^{54}$ Eleinte a gyermekek testi fenyítését is előszeretettel alkalmazták, amely ellen Marcus Fabius Quintilianus foglalt állást. Quintilianus a gyermekek közösségi, intézményi nevelésében hitt, ugyanakkor nagyon fontosnak tartotta az édesanya szerepét a gyermek életében. Quintilianus egy erkölcsileg megromlott Rómában élt, amelyben alapvető veszélyt látott:

„Vajha gyermekeink erkölcseit mi magunk el nem rontanók. Már a csecsemőt nekiszabadítjuk a gyönyöröknek. Az a bizonyos puha nevelés, melyet szelíd

46 Péter (2005): i. m.

47 Tekintettel arra, hogy a lánygyermekek nem számíthattak arra, hogy bármilyen állami tisztséget betöltsenek.

48 A gyermeket 7 éves koráig édesanyja nevelte.

49 Pukánszky-Németh (1996): i. m.

50 Portik (2012): i. m. 78.

51 Lang Tünde: Gyermekkitevés és abortusz a Római Birodalomban. Újkor, 2020. augusztus 2.

52 Romulus alatt keletkezett a lex regia törvény, amely a pater familias számára kikötötte, hogy az összes fiúgyermeket fölnevelje, és a lányok közül az elsőszülöttet tartsa meg, a törvény viszont nem engedélyezte, hogy hároméves kor alatti gyermek életét kioltsák, leszámítva a torzszülötteket. Cicerónál a tizenkét táblás törvényekben is szerepel a gyermekkitevés, amely elrendeli a testi hibával született csecsemő kitételét.

53 Lang (2020): i. m. „Augustus korában nagy volt a gyermektelenség, számos abortuszt hajtottak végre és nagy volt a gyermekkitevések száma."

54 Lang (2020): i. m. 
bánásmódnak nevezünk, a lélek és a test erejét egyaránt megtöri. Aki (mint csecsemő) bíborban úszik, mit nem fog serdült korában megkívánni? Alig ejti ki az első szókat, már megismeri a szakácsot, már osztrigát követel. Elébb műveljük ínyöket, mint erkölcseiket." ${ }^{55}$

Bár kétségtelen, hogy a római gyermek, a család részeként, illetve jövendőbeli tisztviselőként érték volt az antik római társadalomban, de semmiképpen sem beszélhetünk a gyermekröl mint önmagában vettértékröl és önmagáért értékelt személyröl, akit pusztán abból fakadóan, hogy gyermekkorú, differenciált védelem illet.

\section{A középkor gyermeke}

\subsection{A kora középkor}

\subsubsection{Társadalmi alapeszme}

Az antikvitás embere élni akart, és eközben a teljességre törekedett. Testét-lelkét ennek érdekében fejlesztette. Rettegett a haláltól, boldogulását ezen a földi világon kereste. A korai kereszténység embere ezzel szemben a földöntúli élet felé forditotta figyelmét. Nem képességeinek harmonikus fejlesztésére törekedett, hanem arra, hogy halhatatlan lelkét megtisztítsa. ${ }^{56} \mathrm{Az}$ erkölcs forrása alapvetöen nem a tudás, hanem $a$ hit és szeretet volt. ${ }^{57}$ Ez természetesen nem jelentette a tudás megvetését, inkább egy olyan típusú megközelítést, ahol az ember önmagában vett méltósága (szeretete, erkölcsössége) lényegesebb volt az elme pallérozottságánál. A kora középkorban a kereszténység emberi méltóságot erősítő eszméje mellett azonban a realitásban párhuzamosan létezett egy „világi” valóság is, ahol a pogány világból örökölt, néhol barbár szokások, rendkívül rossz higiéniai körülmények és markáns társadalmi különbségek hangosodtak ki.

\subsubsection{Gyermekkép}

\subsubsection{A keresztény gondolkodók gyermekképe}

Az egyházatyák alapvetően azt a bibliai gondolatot közvetítették, hogy a gyermek önmagában véve érték, Isten teremtménye, Istentől kapott lélekkel. Ebből kifolyólag az abortusz a gyermek megölésének számít, így tehát bün. Nem véletlen ezért, hogy a nyugati civilizációban az emberi méltóság abszolút értelmủ elterjedéséhez legna-

55 Pukánszky-Németh (1996): i. m.

56 Pukánszky-Németh (1996): i. m.

57 Fináczy Ernő: A középkori nevelés története. Budapest, Kir. Magyar Egyetemi Nyomda, 1926. 4. (Reprint kiadás: Budapest, Könyvértékesítő Vállalat, 1985.) 
gyobb mértékben a kereszténység járult hozzá. ${ }^{58}$ Meglátásom szerint az emberi méltóságon belül a gyermek emberi méltóságának, speciális értékének, a gyermekkor rendkivüli sebezhetöségének, a gyermek formálhatóságának, az önmagáért való védelem rendkivüli fontosságának a felismerése is alapvetöen ebben a szeretetalapú megközelitésben rejlik. ${ }^{59}$

Szent Ágoston szerint az ember természeti ember, de megvan a lehetősége arra, hogy Isten kegyelme által újjáteremtődve szellemi emberré váljék. ${ }^{60} \mathrm{~A}$ gyermek ösztönei bűnösek (az eredendő bűn miatt), de igazi bűnössé csak szabad akaratából válik. Isten felkínálja az erkölcsi tökéletesedés útját. A szülő és a nevelő szeretettel tudja a gyermek esendő, bűnre hajlamos akaratát a magasrendű lelki célok felé irányítani (ez alapvetően a gyermeknevelés célja is). A legfontosabb szülői feladat az akarat szeretettel történő nevelése. A szeretet - Szent Ágoston szerint - nem zárja ki, sőt egyenesen megköveteli a gyakori testi fenyítést. Szent Ágoston alapvetően hitt a gyermek nevelhetőségében, lelkének formálhatóságában, vizsgálta a gyermek fejlődését és az anya-gyermek kapcsolatot mint a gyermek életének meghatározó tényezőjét.

Szent Ágostonnak a szeretettel való nevelése, a gyermek formálhatóságában való hite ${ }^{61}$ - amely formálhatóság célja végső soron a tiszta szeretet és erkölcsösség, amelynek jutalma az örök élet -, az anya-gyermek kapcsolat misztériumának és a gyermeki lélekre gyakorolt hatásának felismerése valódi újszerüségnek számit. Mindezzel együtt - álláspontom szerint - egyértelmủ, hogy a gyermek testi fenyitése nem lehet eszköze ennek a szeretetnek. A gyermek erkölcsi személyként való elismerése és tisztelete - márpedig a szeretetalapú Isten képére teremtett emberképben, gyermekképben hívő kereszténység ezt az Isten által a Bibliában kinyilatkoztatott üzeneteiben megteszi - megköveteli a testi integritásának minden tekintetben való tiszteletben tartását, az eröszak minden formájának tilalmát és a gyerekek valódi szeretetalapú (szükség szerint, koruk szerint), differenciált és egyéniesitett bánásmódot, akár a családi nevelést, akár az állam szabályozó szerepét tekintjük.

\subsubsection{A „világi” középkor gyermekképe}

A 15. századig - de a szegényebb társadalmi rétegekben még tovább - a mai értelemben vett gyermekkor csak rövid időszak volt, hat-hét éves korig tartott. Philippe Ariès

58 Frivaldszky János: Az emberi személy és annak méltósága jogfilozófiai perspektívában - különös tekintettel a jogalanyisághoz és az élethez való jog aktuális kérdéseire. Acta Humana, 2. (2014), 1. 7-74.

59 374-ben született az az egyházi törvény, amely a gyermekek meggyilkolását főbenjáró bűnnek bélyegzi. A 442-ben megtartott vaisoni zsinat határozata értelmében a „kitett” gyermekeket templomokba, kolostorokba kellett vinni, ahol felnevelték őket: papok, szerzetesek lettek belőlük. Az egyház gyermekvédő, karitatív tevékenységének erősödését jelzi a lelencházak megszervezése. Az első árvaházat Dateo, Milánó érseke szervezte meg 787-ben.

60 Pukánszky-Németh (1996): i. m.

61 Bár a gyermek formálhatósága nem volt igazi újszerűség, hiszen azt már az antik kultúrák emberei is látták és „kihasználták”, a gyermek „örökéletre való alkalmasságra” történő nevelése megtisztította az öncélúságtól. 
szerint a középkori ember a gyermekre mint kicsinyített felnőttre tekintett, ezzel szemben Sulamith Shahar vagy Linda Pollock úgy vélekedtek, hogy a gyermekkort már akkor is számításba vették a felnőttek.$^{62}$ Egy biztos, a középkorban a gyermeket hétéves koráig nem tartották igazán értékes lénynek, önállóan értékelhetô személynek pedig semmiképp. Hétéves kora után szinte átmenet nélkül a felnöttek világába került. Felnőttként kezelték, és felnőttes viselkedést vártak el tőle. Nem törődtek azzal, hogy fogékony lelke miként reagál a káros hatásokra. ${ }^{63} \mathrm{~A}$ gyerekkel való foglalkozás főként az oktatásra és a fegyelmezésre (verésre) korlátozódott. A gyermekkor értékként, a gyermek értékelhető személyként történő kezeléséröl, meglátásom szerint, nem beszélhetünk, sőt e tekintetben a „világi középkor gyermekképe” jelentősebb viszszalépést jelentett az antik kultúrák gyermekfelfogásához képest is.

\subsection{A reneszánsz és a humanizmus}

\subsubsection{Társadalmi berendezkedés (alapeszme)}

A 14-15. századi Itáliából induló reneszánsz alapvetően az antik görög és római szerzők gondolatvilágának „újjászületéséből” indult. A reneszánsz az egyéniség érvényesítésének korszaka, erősen emberközpontú, ugyanakkor vallásos (bár a dogmák tekintetében szabadabb) ${ }^{64}$ gondolkodás jellemezte.

\subsubsection{Gyermekkép}

A reneszánsz humanistái a gyermekkort az ártatlanság korának tekintették. A kisgyermek védelemre szorul, erkölcsileg kialakulatlan, a nevelés nemcsak az ismeretek átadását, hanem egyben az erkölcsi gyarapítását is jelentette. ${ }^{65}$ Annak ellenére, hogy a gyerekek nagy részének életkörülményei a kora középkorhoz képest a 15-16. században nem sokat javultak, mégis kialakulófélben volt egy új szülói magatartás, gyermekek iránti attitüd, amely a gyerekek, a gyermekkor fokozatos felértékelödését eredményezte. ${ }^{66}$

Erasmus szerint a gyermekkor a potenciális alaktalanság korszaka, ${ }^{67}$ amely állapotból a nevelőnek kell jellemet, embert formálnia. A gyermek nevelése pedig alapvetően a szülő́k másra át nem ruházható feladata, amelyet az iskola intézménye tud kiegészíteni. Klasszikus humanista szerzőként Erasmus meghaladva korát, amellett

62 Hollósi Hajnalka: Gyermekkép, gyermekvilág, gyermekfelfogás változásai pedagógiai megközelítésben. Iskolakultúra, 2. (2008). 92-103.

63 Pukánszky-Németh (1996): i. m.

64 Pukánszky-Németh (1996): i. m.

65 Pukánszky-Németh (1996): i. m.

66 Ez egy alapvetően lassú, ellentmondásokkal tủzdelt folyamat volt, ahol egyrészről a figyelem a gyermekkorra irányult, másrészről viszont a középkor hatása egyértelműen tetten érhető volt.

67 Pukánszky Béla: A gyermekkor története. Budapest, Műszaki Könyvkiadó, 2001.14. 
foglalt állást, hogy a gyermekkor sajátosságait és a gyermek egyéni adottságait figyelembe kell venni. ${ }^{68}$

Morus Tamás a gyermekfelfogás tekintetében kiemelkedő gondolkodója volt a reneszánsznak, a gyermekcentrikus gondolkodásmód egyik első igazi önazonos alakja. ${ }^{69}$ A nevelés eszközének a szeretetet és a gyengédséget tartotta, a testi fenyítést elutasította.

Montaigne - Erasmushoz hasonlóan - lényegesnek tartotta a gyermek erkölcsi nevelését, amely abban a korban egyáltalán nem volt természetes. ${ }^{70}$ Montaigne rácsatlakozott a kibontakozó új eszményre, a gyermeki ártatlanságra. Erkölcsi védelmét elsődlegesnek tartotta, és a gyermeket önmagában való értékként kezelte. A gyermek nevelésénél elutasítja a szélsőségeket, sem az elkényeztetést, sem a testi fenyítést nem támogatja, meglátása szerint a gyermeknevelés eszköze a szeretetteljes szigor kell hogy legyen.

A humanista gondolkodók gyermekfelfogása elöremutató, úttörő, a gyermek személyének, határainak alapvető tiszteletben tartására, erkölcsi formálhatóságára és az erkölcsi formálás szükségszerűségére, mindemellett a szeretet és a gyengédség fontosságára mutatott rá, de sajnos szinte egyáltalán nem tükrözte a társadalmi valóságot. A korszakot követő gondolkodók, ha nem is elsöpörték, de jelentösen elodázták a gyermek speciális és valódi igényeire érzékeny szemléletmódot, a gyermek igazi értékként való kezelését.

\section{Az újkor gyermekei}

\subsection{A reformáció}

\subsubsection{Társadalmi alapeszme}

A 16. században a reneszánsz mellett a reformáció tört magának utat, amely alapvetően szembehelyezkedett a reneszánsz, humanista elvekkel. A reformáció elvi szinten a kiüresedett, hierarchikus egyházi keretek között megélt hitélet ellentéteként, a személyes, bensőséges, mélyen átélt vallásosságot hirdette. ${ }^{71}$ Szigorú hitújítási folyamatok indultak, amelyek elérték a hétköznapi embert, és alapvetően akadályozták a humanista gondolkodók elméleteinek elmélyülését, illetve a gyakorlatra való kivetülését.

\subsubsection{Gyermekkép}

A reformáció gyermekképe Luther gondolatai, elvrendszere mentén tisztán kirajzolódik. Luther szerint a gyermek Isten számára megóvandó, örök kincs.

68 Pukánszky-Németh (1996): i. m.

69 Saját gyermekeit is kiemelkedő gyengédséggel nevelte.

70 Pukánszky-Németh (1996): i. m.

71 Pukánszky-Németh (1996): i. m. 
Családeszményében a szülőnek, elsősorban az apának teljhatalma van a gyermek felett, és ezt a teljhatalmat a gyerek születésekor alapvetően romlott természetéből való kinevelésre és az erkölcsre való ránevelésre kell használni. Ehhez pedig Luther szerint érzelemmentességre, testi fenyítésre, a gyerek akaratának megtörésére van szükség. A reformáció elvrendszerébe illeszkedő gyermekfelfogás, bár a gyermek istengyermeksége miatt kincsként tekintett rá, egyértelmü, hogy nem forditott kellö figyelmet a gyermekkor speciális jellegére, a gyermekre mint önálló személyre, és a szeretettel nevelése helyett a szigorú erkölcsösséget hangsúlyozta.

\subsection{A felvilágosodás 17. századi elöszele}

\subsubsection{Társadalmi alapeszme}

A 17. század átmeneti időszakot képez a középkori gondolkodásmód és a felvilágosodás között. Lezajlott egyfajta technológiai, orvostudományi fejlődés, amelynek köszönhetően megindult a társadalom a felvilágosodás felé vezető úton.

\subsubsection{Gyermekkép}

A korábbi évszázadokra jellemző, a gyermeket érzelmi távolságban tartó attitüd - köszönhetően annak is, hogy az orvostudomány fejlődése lehetővé tette, hogy egyre több gyermek élje meg a felnőttkort - átalakulni látszott. ${ }^{72}$

A felvilágosodás előfutárának tekintett Locke Gondolatok a nevelésről címü műve szerint egy gyermeknek egészséges testtel, jókedvvel, erényes vallásos lélekkel és praktikus ismeretekkel kell rendelkeznie, ${ }^{73}$ legalábbis nevelésének célja mindenképp ez kell hogy legyen. ${ }^{74}$ A gyermek pedig Locke szerint nevelhetö, formálható és nevelendő is, aminek leghatásosabb módja a személyes példaadás. A formálásnak és példaadásnak pedig elsősorban az erkölcsiségre kell irányulnia. Locke szerint: „Az ember legfőbb értékmérője nem a tudás, hanem az erkölcsiség." Mủvében a gyereknevelés praktikumairól is ír, elvei és tanácsai a maga korában forradalmian újnak számítottak. ${ }^{75}$

72 Hollósi (2008): i. m.

73 Faix Nikoletta: A gyermeki jogok kialakulása a nemzetközi jogban és az igazságszolgáltatásra gyakorolt hatásuk. Eljárásjogi Szemle, (2016), 4. 8-15.

74 Locke embereszménye az angol gentleman.

75 Lux Ágnes: A gyermekjogi mozgalom fejlődése és az európai független gyermekjogi intézmények összehasonlitó perspektívában. Doktori (PhD-) értekezés. Budapest, Eötvös Loránd Tudományegyetem, 2018. 


\subsection{A felvilágosodás}

\subsubsection{Társadalmi alapeszme}

A felvilágosodás gondolatvilágának jellemzője a liberalizmus, azaz a szabadgondolkodás, amely az emberi értelem teljes autonómiáját, függetlenségét hirdette. Tagadta a vallási dogmákat és az egyházat. A keresztény hitből csak azt fogadta el, ami emberi ésszel felfogható, és ami az erkölcsös élethez elegendő. Isten mint a világ megalkotója létezik, de mivel Isten önmagában tökéletes és tökéletes világot alkotott, beavatkozása, gondviselése szükségtelen (deizmus). Az ember feladata, hogy észszerü, erkölcsös életet éljen, azonban ehhez nincs szüksége élő vallásosságra.

\subsubsection{Gyermekkép}

A felvilágosodás gyermekképe reagált arra a drasztikus francia pedagógiai módszerre, amely ellen már a humanista gondolkodók is szót emeltek, és amelyben a gyermeknevelés alapvető eleme volt az erőszak. A felvilágosodásban először találkozunk a gyermekkel mint lehetséges jogalannyal: Thomas Spence $A$ kisgyermekek jogai címü munkájában megfogalmazta, hogy a gyermeknek joga van a föld gyümölcseinek élvezetében való teljes részesedéshez. ${ }^{76} \mathrm{~A}$ felvilágosodás gondolkodói a „jövő zálogát” látták a gyermekekben, amit igen érdekes összevetni az ősközösségek és az antik kultúrák „túlélés zálogaként” kezelt és a középkor „bűnben fogant”, az örökéletre formálandó és alakítandó gyermekével. Loyd de Mause kutatása szerint a 18. század előtt született gyermekek többsége bántalmazottnak tekintendő, ${ }^{77}$ és az időbeli áttekintésnek ezen a pontján nincs is okunk ezt megcáfolni. Inkább megerősíteni és hozzátenni azt, hogy bár a 18. század kétségtelenül fontos elméleti kijelentések időbeli színtere, a „bántalmazott gyermek” mint ,jelenség”, a legkülönbözőbb formákban, a 18. század valóságában igen szomorú módon, hétköznapi volt, ${ }^{78}$ és egészen a mai napig láthatóan és láthatatlanul is fellelhető, sőt nem is olyan régen még szabályozási szinten sem volt egyértelműen elutasítva. ${ }^{79}$

A felvilágosodás gyermeke Locke tanítványának, Rousseau-nak Emil, avagy a nevelésről című művében rajzolódik ki igazán, amelyben Rousseau a humanizmus által megfogalmazott ártatlanságot hívja elö. Ebben az értelemben a gyermek tehát eredendően jó (csak a társadalmi együttélés rontja el). ${ }^{80}$ Rousseau erősen hitet tesz a gyerekkor és annak fontossága mellett: „Hagyjátok megérni a gyermekkort a gyermekben." Rendkívül fontos mondat ez, nemcsak gyermeknevelési, gyermekpszicho-

76 Faix (2016): i. m.

77 Lux (2018): i. m.

78 Lux (2018): i. m. 23. Daniel Defoe az 1720-as évek angol textilgyárai kapcsán írta, hogy már a „4-5 éves gyermekek a saját betevőjükre valót keresik meg”.

79 Magyarországon 2005. január 1-je óta tiltott a gyermekek testi fenyítése.

80 Jean-Jacques Rousseau: Emil, avagy a nevelésröl. Budapest, Tankönyvkiadó, 1978. 11. 
lógiai szempontból, hanem gyermekjogi nézőpontból is. Egyszerre mutat rá a gyermekkor speciális érzékenységére, megélésének fontosságára, arra, hogy milyen elemi ereje van mindannak a tapasztalásnak, nevelésnek, gondoskodásnak, amit egy ember a gyermekkorában kap, milyen elvitathatatlanul meghatározó a gyerekkor a tekintetben, hogy kiből milyen felnőtt válik, és ezekből a felnőttekből milyen állapotú társadalom formálódik, és arra, hogy a gyerekkornak e speciális jellemzői egyértelmüen megkövetelik a megfelelő és differenciált védelmet makro- és mikroszinten egyaránt.

Visszatekintve Rousseau gyermekképe azonban, saját életének példájából fakadóan, ellentmondásokkal teli, hiszen saját öt gyermekét lelencházba adta, és ez számunkra aligha nevezhető boldog gyerekként megélt gyerekkornak - ellentétben a humanista Morus Tamással, aki a gyermekközpontúságot önazonosan tudta képviselni.

\section{A 19. század}

\subsection{Társadalmi alapeszme}

Általánosan jellemző mondatokat a 19. század kapcsán még nehezebb írni, mint az ezt megelőző évszázadokról. A gyors társadalmi fejlődés, átalakulás, rohamos technológiai innováció számos eszme párhuzamosságát, országok szerinti differenciáltságát hozta. Az előző évszázadokhoz hasonlóan ugyanakkor megfigyelhető a valóságnak egyfajta kettős szintje. Egyrészt léteztek és a középosztály körében terjedni látszottak - elsősorban a gondolkodók, filantrópok ${ }^{81}$ nyomán - az emberi, humanitárius szempontokat elsődlegesnek gondoló hangok, másrészről a munkásosztály valósága megkerülhetetlen volt. A munkásosztály valóságában pedig elsődlegesnek látszottak a gazdasági, üzleti érdekek, amely érdekek hozzájárulására szükség volt ahhoz, hogy a szabályozás szintjén bármilyen humánus (akár gyerekvédelmi) szempontot figyelembe vegyenek. ${ }^{82}$

\subsection{Gyermekkép}

A 19. század filantróp valóságából Kantra érdemes rátekinteni. Kant szerint az édesanya kötelessége a gyermek táplálása, ugyanakkor szembehelyezkedik a felvilágosodás érzelemgazdag, boldog gyermeket nevelő megközelítésével, és amellett foglal állást, hogy a kényeztetést, túlzott érzelmi kötődést kerülni kell. ${ }^{83}$ A nevelés mindenekelőtt a jövőnek szól: ${ }^{84}$

81 Lux (2018): i. m.

82 A. R. Colón - P. A. Colón: A History of Children. A Socio-Cultural Survey across Millenia. Westport, Greenwood Press, 2001. 457.

83 Pukánszky-Németh (1996): i. m.

84 Kant látja a nevelés előtt tornyosuló akadályokat is: a szülők a jelenre, s nem a jövőre készítik föl gyermekeiket, az uralkodók pedig egyszerüen úgy tekintenek alattvalóikra, mint céljaik elérésének eszközeire. 
„Talán remélhetjük, hogy a nevelés mindig jobb és jobb lesz, és hogy minden következő nemzedék egy lépéssel közelebb jut az emberiség tökéletesedéséhez, mert az educatio mögött rejlik az emberi tökéletesség nagy titka. [...] Nagyszerü dolog elképzelni, hogy az emberi természet folytonosan jobbítható a neveléssel. Ez egy jövendő, boldog emberi nem reménységét nyújtja nekünk."

Fontos és lényeglátó megállapítás ez, amely bár elsősorban a nevelés kontextusára szűkíti le a jobbítás képességét, de ugyanilyen átívelő hatása van a megfelelő gyermekjogi garanciák biztosításának, illetve a gyermek legfőbb érdekét szem elött tartó attitűd folyamatos és tudatosított alkalmazásának is. Bármennyire igaz is, mégsem teljes a Kanttól kapott kép, hiszen kulcsfontosságú kérdésben látja másképp a gyermeket, mint ami ahhoz szükséges, hogy az általa prekoncepcionált jövő megvalósulhasson, ez pedig a kényeztetésnek nevezett érzelmi biztonságadás, amely alapvető módon biztosítja a gyermek számára a megfelelő fejlődést.

A gyermekkép változása és fejlődése szempontjából igen fontos a munkásosztály tényleges valósága is, hiszen lényegében az innen induló, elsősorban a gyermekmunka visszaszorítását célzó „gyermekvédő mozgalmak" ${ }^{85}$ vezetnek át a gyermek évszázadának is nevezett 20. századba. Ezek a "gyermekvédő mozgalmak" az elburjánzó gyermekmunka szabályozásának megakadályozása érdekében hoztak egyfajta differenciált, életkor szerinti megközelítést, amely immáron a szabályozás szintjén is elismerte a gyermekkor sérülékenységét, illetve a sérülékenység különböző életszakaszokhoz kapcsolódó eltérő jellegét. ${ }^{86}$

\section{A modern kor (a gyermek évszázada)}

\subsection{Társadalmi alapeszmék}

A 20. század első felében lezajlott I. világháborút követően a nemzetközi szervezetek és az államok elkötelezödtek az emberi jogok védelme mellett, amely folyamat a II. világháborúval megszakadt, és a világ soha nem látott mértékủ emberi jogi jogsértések színtere lett. A borzalmakból felocsúdó államok a háború végével új lendületet kaptak, és a háború alatt elfeledett emberi jogok soha nem látott ütemben kerültek keretek közé.

85 Lux (2018): i. m. 24.

86 Magyarországon a gyárak jogviszonyairól szóló 1840. évi XVII. törvénycikk kimondta, hogy a 12. életévüket be nem töltött gyermekeket csak olyan gyári munkára lehetett alkalmazni, amely egészségükre nem ártalmas, testi fejlődésüket nem akadályozza. A 16 év alatti gyermekek naponta legfeljebb 9 órát dolgozhattak, egyórás pihenőidővel. Az 1884. évi XVII. törvénycikk szerint 10 év alatti gyermek egyáltalán nem, 10-12 év közötti csak az iparhatóság engedélyével alkalmazható gyárban, ha munkája mellett iskolába is tud járni. 


\subsection{Gyermekkép}

A 20. század erős szélsőségeket hordoz. A történelmi viharok egész generációkat traumatizáltak, amely traumáknak máig átívelő, sokrétű hatása van. Hiába fogadta el a Népszövetség 1924-ben, Genfi Nyilatkozat néven a Gyermekek Chartáját, a II. világháborúban sokszorosan ismétlődött meg a menekült és menekülő gyermekek tragédiája. A náci haláltáborokban - az ismert adatok alapján - körülbelül 1,2 millió zsidó gyermeket végeztek ki vagy haltak meg a Mengele-féle orvosi kísérletek során. ${ }^{87}$ A pontos számok ismerete nélkül, a becslések szerint, körülbelül 25 millió civil áldozatot követelt a háború, amely a gyermekpopulációra vetítve 10 millió halálos áldozatot jelentett. ${ }^{88}$

Ugyanakkor nem véletlenül nevezzük a 20. századot a gyermek évszázadának. Gyermekképről ekkor már nem csupán pedagógiai, neveléslélektani, pszichológiai nézőpontokból beszélhetünk, hanem a gyermek mint emberi jogi jogalany is körülíródik. Ennek legelső, valóban átfogó jogi dokumentuma az ENSZ Gyermekjogi Egyezménye, amelyet 1989-ben az ENSZ Közgyủlés egyhangúan fogadott el 44/25. Határozatával. Az Egyezmény értéke meghatározó, többek között azért is, mert a gyermek nem „csak” mint emberi jogi jogalany jelenik meg, hanem speciális, gyermeki jogok jogalanyává is válik.

Az Egyezmény számos olyan fogalmat és elvárást vezetett be, amely alapvetően meg kell(ene), hogy határozza az összes olyan teret, mind elvont társadalmi, mind szabályozási, mind konkrét fizikai értelemben, ahol gyermekekkel foglalkoznak. A teljesség igénye nélkül ilyen fogalom, illetve elvárás a gyermek legfóbb érdekének mindenkori érvényesülése. Az Egyezmény gyermekkorfogalma is közelebbi rátekintésre hív, meghatározza ugyanis a gyermekkor felső határát, az alsóra azonban nem vállalkozik. Preambulumában kimondja, hogy „tekintettel a gyermek fizikai és szellemi érettségének hiányára, különös védelemre és gondozásra van szüksége, nevezetesen megfelelő jogi védelemre, születése előtt és születése után egyaránt”. Önmagában ez a preambulumi mondat hosszabb jogfilozófiai átgondolásért és elemzésért kiált, ám ezen a ponton ez meghaladná ennek a tanulmánynak a kereteit. Számos szerző ${ }^{89}$ foglalkozik az emberi élet kezdetének jogfilozófiai jelentőségével, amely mủvek rámutatnak arra, hogy milyen sikamlós terepre érkezik a jogszabályalkotó, amikor erre a területre téved. Az Egyezmény tárgyalói az emberi és így gyermeki élet kezdetéhez kapcsolódó állásfoglalások megtételét az Egyezményt ratifikáló államokra bízták, és e tekintetben jól tették, hogy ezt az igen fontos nemzetközi jogi dokumentumot és a benne foglalt gyermeki jogokat megóvták egy olyan elhúzódó vitától, ${ }^{90}$ amely esetlegesen meggátolta volna a gyermeki jogok valódi érvényesülésének teret nyitó folyamatot, azaz az Egyezmény ratifikációját. ${ }^{91}$

87 Lux (2018): i. m.

88 Lux (2018): i. m.

89 Lásd például Frivaldszky (2014): i. m.

90 Lásd Isztambuli Egyezmény.

91 Megjegyzendő, hogy az ENSZ Gyermekjogi Egyezményt egyedül az USA nem ratifikálta. 
A 20. századi gyermekkép nemzetközi jogi kereteinek formálódása mögött zajlott egy pszichológiai változás, nevelési forradalom, amely mind hozzájárult a gyermeki lét, a gyermekkor mélyebb megértéséhez, és elválaszthatatlan módon alkot egységet az ENSZ Gyermekjogi Egyezményében lefektetett gyermekjogokkal. Ez pedig nem más, mint az a folyamat, amely egyre erősebb érzelmi közelségbe hozta egymással a szülőt és a gyermeket. E tekintetben - a teljesség igény nélkül kiemelendő a behaviorizmus irányzata és dr. Spock forradalminak számító gondolatai.

A behaviorizmus Pléh szerint nem csupán módszer, hanem bizonyos fokig emberkép is. Lényege, hogy a környezeti ingerek optimális szabályozása elvezet a gyermekek egészséges személyiségformálásához. A helyes viselkedést megerősítő jutalmak és a helytelen viselkedéseket követő következetes és megfelelő mértékủ (minimálisan elégséges) büntetések elvezetnek ahhoz, hogy a személy viselkedése megfelelö legyen. ${ }^{92}$ Skinner, az irányzat atyja szerint a jutalmat kell elsősorban alkalmazni. A gyermekek helyes viselkedését meg kell erősíteni, és ezzel csökkenthető az erőszak, a helytelen viselkedések büntetése a káros mellékhatások miatt.

Dr. Spock ${ }^{93}$ gyermekorvos Csecsemö- és gyermekgondozás címü könyvében megerősíti a szülőket azzal, hogy leírja, a saját gyermekeikhez ők értenek a legjobban. Azt tanácsolta, hogy a síró gyermekeket vegyék fel, nyugtassák meg, mert az ölelés és a szeretet és az ebből fakadó biztonság kiegyensúlyozottabbá, boldogabbá teszi őket. Hangsúlyozta, hogy minden gyermek külön egyéniség, így nem vonatkozhatnak általános és merev szabályok fejlődésükre. Nem helyeselte a fegyelmezésen és verésen alapuló, dogmatikus nevelést. Azt hangoztatta, hogy szülőnek lenni öröm, a nevelést élvezni, a gyermeket tisztelni és szeretni kell. Spock, könyvének újabb és újabb kiadásaiban szükség szerint módosította tanításait. Fontosnak tartotta az apa szeretetét a nevelésben, szorgalmazta a családon belüli munkamegosztást és így a dolgozó anyák terheinek csökkentését, és rámutatott a szeretet felelősségére is, arra bátorítva a szülöket, hogy merjék a gyermekek számára ártalmas dolgokat megtiltani.

\section{A 21. század és a jövő gyermekei}

\subsection{Társadalmi alapeszmék harcai}

A szélsőségek évszázadát éljük.

Egyrészt szeretünk abban a köntösben tetszelegni, hogy a társadalmunk soha nem volt ilyen fejlett és civilizált, másrészt a valóság az, hogy egy fenntarthatatlan, az eröszak rejtett és nyílt formáitól nem visszariadó, mindent relativizáló világ vesz minket körül, ahol világnézetek ütköznek, a leghétköznapibb események során is.

Bár a szemünk egyre inkább kinyílik arra, hogy lássuk a néha láthatatlan erőszakot, az erőszak gyakran mégsem éri el a cselekvésre ösztönző ingerküszöböt, vagy

92 N. Kollár Katalin - Szabó Éva: Pszichológia pedagógusoknak. Budapest, Osiris, 2004.

93 A gyermeknevelés „eretneke” és médiasztárja - száz éve született Benjamin Spock. Gondola, 2003. május 1. 
az ingerküszöb az egyes világnézetek függvényében alakul, és egészen más mintázatot mutat attól függően, hogy mely világnézet szemüvegét viseljük. A rohamos digitalizáció pedig újabb és újabb tereit nyitja meg ennek a nehezen megfogható erőszaknak, amelyhez a társadalom kéretlenül, kortalanul és korlátlanul hozzáfér. A kérdés, hogy van-e az erőszaknak általános mércéje, nem ennek a tanulmánynak a témája, egy dolog azonban biztos: az erőszakot nem lehet egyetlen tényezővel leírni, mindenhova begyưrüzhet, és néha valóban láthatatlan és a láthatatlanságból fakadóan talán felismerhetetlen is. Az erőszak jelenlétének és a fenntarthatatlanság tudatosítása pedig igen sürgető, tenni ugyanis csak az ellen lehet, amit felismerünk. Meglátásom szerint a 21. század embere olyan terepen él, ahol bár hosszú idő óta nincs fegyveres konfliktus, az ideológiák harca és az észrevétlenül begyürüző erőszak mindennapos konfrontációkat szülnek, mind a közösségi, mind az egyéni valóságban. Kétségtelen és tagadhatatlan azonban, hogy az ember ebben a térben is küzd, néha egyéni, néha közösségi szinten egy, a békét kevésbé relativizáló és abszolút igazságokban hívő, erkölcsösebb és erőszakmentes valóságért.

\subsection{Gyermekképek harcai}

De mit tesz a gyerekekkel a szélsőségek és a láthatatlan eröszak évszázada?

Erősen hiszem, hogy a Gyermekjogi Egyezmény abban a hitben és meggyőződésben és azért született, mert a gyermeket az emberi létből és a hozzá kapcsolódó elvitathatatlan emberi méltóságból fakadóan teljes értékü erkölcsi lénynek tekinti. ${ }^{94}$ Azonban, ha a mélyére nézünk ennek a kérdésnek, sajnos rögtön látjuk a bizonytalanságokat, amely első ponton a gyermekkor alsó határának meghatározásából fakad. És bár a Preambulum kimondja, hogy a gyermek a születése előtt is védendő, éppen a születése előtti legkiszolgáltatottabb időszaka vonatkozásában legbizonytalanabb a védelme, azáltal, hogy ki van szolgáltatva az egyes nemzeti jogalkotók jogfilozófiai megközelítésének. Ez pedig a 21. században a legkülönfélébb világnézeti megközelítések tükrében akár az élethez való jogának relativizálódásához is vezethet. Ez a fajta relativizálódási veszély, bizonytalansági faktor sajnos a Gyermekjogi Egyezmény gyermeki jogainak tartalma szempontjából is fennállhat. Elég, ha csak arra tekintünk, hogy az Egyezményt a Vatikán is ratifikálta, amelynek világnézeti hovatartozása egyértelmü határokat jelöl ki arra, hogy a Vatikán miként értelmezheti az Egyezményben foglalt gyermeki jogokat.

Szép példája ennek a relativizálódási lehetőségnek a gyermekek családhoz való joga. A kisgyermekek, gyermekek olyan teljes jogú személyek, akik meghatározott élethelyzetben vannak a családi és egyéb társadalmi relációkon belül, vagyis nem kicsi felnőttek, ${ }^{95}$ kicsi jogokkal. Emberi személyek, akiknek sérthetetlen méltósága van, pusztán emberi létezésük okán, ${ }^{96}$ emberi személyiségük kiegészül azzal a többletjel-

94 Frivaldszky (2013): i. m. 98.

95 Frivaldszky (2013): i. m. 105.

96 Frivaldszky (2013): i. m. 101. 
leggel, hogy gyermekek, speciális gyermeki jogokkal, akik felé különös érzékenységgel és mindig legfőbb érdekük szem előtt tartásával kell fordulni. Ezeknek a gyermekeknek a legfóbb joga és legfóbb érdeke a családon belüli nevelkedéshez való jog. ${ }^{97}$ Sem absztrahált, sem pedig konkrét értelemben véve nem tesz jót a gyermeknek az a társadalmi feszültség, amely a család fogalma körül zajlik. Ugyanakkor az egészséges lelki fejlődés alapvetése a gyermek életében az egymás felé szeretettel forduló anya és apa képe, és a felé, anyai és apai szeretettel forduló szülökhöz való kötődés. Ehhez a fajta szülőképhez, a családhoz való jogából fakadóan, a gyermeknek joga van. Nehéz egyéni sorsok, egyedi helyzetek vannak, amelyek felé kötelességünk mikro- és makroszinten is érzékenyen fordulni, az érintett személyek emberi méltóságát és emberi jogait pedig kompromisszum nélkül tiszteletben tartani. Ugyanakkor elfelejthetetlen az az alapvetés, hogy egyelőre alapjogként még nem született meg a gyermekhez való jog, ${ }^{98}$ de a gyermek „Családi és egyéni jogai igenis léteznek”.99 Ebben a tekintetben tehát a jogalkotónak mindig is a gyermek legföbb érdeke mellett kell kiállnia, és azt kell támogatnia, tehát mindamellett, hogy empatikusan fordul a partikuláris sorsú felnőttek felé, a gyermek-anya-apa által alkotott család mellett kell állást foglalnia.

Az emberiség évszázadokig a felnőtt ember tulajdonának, a nevelés és gyakorta az eröszak tárgyának tekintette a gyermeket. Ma már - köszönhetően a neveléslélektan, a pedagógia és pszichológia megállíthatatlan fejlődésének - tudjuk - legalábbis elméleti szinten -, hogy mik egy gyermek szükségletei. A prenatális pszichológia ${ }^{100}$ arról beszél, hogy igenis van magzati emlékezet, és mindaz, ami magzati korunkban, illetve újszülött korunkban történik velünk, mélyen beleivódik személyiségünkbe, és tudat alatt meghatároz minket. Az oly gyakran emlegetett kötödő nevelési irányzat szerint valóban egészséges lelkủ gyermeket erőszakmentesen úgy tudunk leginkább nevelni, ha figyelünk a szükségleteire, válaszkészek vagyunk, és válaszolunk is nemcsak a fizikai, de az érzelmi, lelki szükségleteire, finoman szabunk határt, elsősorban (nem túlzó) következményekkel, és a büntetés minden formáját mellőzük. ${ }^{101}$ Természetesen ez a gyakorlatban nem annyira egyszerü, különösen generációkon átívelö, mikro- és makroszinten megélt traumákat hordozva. Ma már azt is tudjuk

97 Frivaldszky (2013): i. m. 105.

98 Frivaldszky (2013): i. m. 106.

99 Frivaldszky (2013): i. m. 107.

100 A perinatális szó jelentése „születés közeli”. Jelzőként azt értjük rajta, hogy foglalkozik a fogantatás, a várandósság, a magzati lét, a születés és szülés, a gyermekágy, a csecsemőkor és a fiatal családok pszichológiájával. Egy összetett, interdiszciplináris tudomány, a perinatális tudomány része a perinatális pszichológia. Az elmúlt két évtized kutatásai egy rendkívüli tudományos eredményt fogalmaztak meg: a magzat kompetens saját életében, észlel, emlékezik és viselkedését meghatározza mindaz, amit tapasztal fogantatásától kezdve. Ez azt jelenti, hogy az egész emberi életet megalapozza és meghatározza mindaz, amit ebben az időszakban tapasztaltunk. Nem mindegy, hogyan bánik egy várandós anya, ifjú apa vagy a szülést kísérő szakember a babával, mert ez kihat a sorsára.

$101 \mathrm{Ez}$ nem jelenti azt, hogy válogatás nélkül mindent szabad a gyermeknek. Egy szülőnek igenis bátran kell nemet mondani, éppen a gyermek legfőbb érdeke miatt azokra a helyzetekre, amelyek a gyermek számára ártalmasak. Benjamin Spock: Dr. Spock on Parenting: Sensible Advice from America's Most Trusted Child-Care Expert. New York, Simon \& Schuster, 1988. 
azonban, hogy a feszült, maximalizmusvezérelt szülő nem lesz képes a kötődő nevelésben rejlő lehetőségeket jól használni a gyermeknevelésben. Ezért is született meg az „elég jó szülo”"102 fogalma. Az elég jó szülő pedig folyamatos jóindulatú törekvést jelent mind a pozitív nevelési technikák, mind a gyermekek jogait tudatosító attitűd felé. A pozitív nevelési technikák tudatos alkalmazása pedig csak megerősíti a szerető család elvitathatatlanul erös és a gyermek legföbb érdekét szolgáló védelmi funkcióját.

Mikroszinten feladatunk tehát úgy védeni a gyermekeinket, hogy válaszkész, elég jó szülók vagyunk. Ennek keretében óvjuk a családjaink épségét, és próbáljuk elkerülni azt, hogy belecsússzunk a régebbi korok hibájába, és pusztán azért, mert felnőttek vagyunk és jobban értjük és érezzük a saját igényeinket és vélt vagy valós jogainkat, a gyerekeket észrevétlenül is erőszaktárgynak tekintjük azzal, hogy relativizáljuk a jogaikat, és a gyermek legfőbb érdekének elvével szembe menve a saját jogainkat tekintjük zsinórmértéknek. Nem lenne ez a jogalkotó feladata is a gyermekekkel kapcsolatban? Rátekinteni, válaszolni és „elég jó” államnak lenni? Nem ezt érezzük hiányosságnak a történelmi korokat végigtekintve, hogy az állam, az intézmények kérlelhetetlen és szigorú uralkodószékéből tekintettek a gyermekre, és nem próbáltak belehelyezkedni a gyermeki szükségleteket valóban figyelembe vevő székbe?

Két éve volt 30 éves az ENSZ Gyermekjogi Egyezmény. Hiába telt el 30 év, a gyermekjogok valódi és teljes érvényesülése, azaz a gyermekkor differenciált sajátosságainak tényleges megértése és így a gyerekek hatékony védelme még hosszú folyamat előtt áll, amely úton azonban nem szabad megállni. Ugyanis az, hogy mivé lesznek a 21. század gyermekei, még nem dőlt el végérvényesen, a jövőt mi adjuk a kezükbe: figyeljünk rájuk, hallgassuk meg őket, ne hagyjuk, hogy a láthatatlan és látható eröszak elérje őket, és ami a legfontosabb és mindennek az esszenciája: ne relativizáljuk az őket abszolút értelemben megillető jogokat, tehát a történelem során először kezeljük őket valódi értékként.

\section{Irodalomjegyzék}

Albert Gábor: A nevelés történeti és elméleti alapjai. Kaposvár, Kaposvári Egyetem, 2011. Online: www.dralbertgabor.hu/images/albert_gabor_nevtort_jegyzet.pdf

Ariès, Philippe: L'enfant et la vie familiale sous l'Ancien Régime. Revue française de sociologie, (1960), 1-4. 486-488. Online: https://doi.org/10.2307/3319068

Berzsenyi Emese: A társadalmi gondoskodás és tanítás történelmi előképei. Iskolakultúra, 25. (2015), 9. 100-112. Online: https://doi.org/10.17543/ISKKULT.2015.9.100

Bettelheim, Bruno: Az elég jó szülö. Budapest, Park, 2018.

Colón, A. R. - P. A. Colón: A History of Children. A Socio-Cultural Survey across Millenia. Westport, Greenwood Press, 2001.

102 Bruno Bettelheim: Az elég jó szülő. Budapest, Park, 2018. Az elég jó szülö mindig tudatában lesz, hogy gyermeket foganni, kihordani és világra hozni életének legcsodálatosabb eseménye. A születés pedig a gyermek életében a legcsodálatosabb esemény. Minél jobban élvezik mindazt a maguk módján, ami ebből következik - a szülő a gyermeknevelést, a gyermek azt, hogy a szülő neveli -, annál boldogabb lesz az életük. 
Faix Nikoletta: A gyermeki jogok kialakulása a nemzetközi jogban és az igazságszolgáltatásra gyakorolt hatásuk. Eljárásjogi Szemle, (2016), 4. 8-15. Online: https://eljarasjog.hu/2016-evfolyam/a-gyermeki-jogok-kialakulasa-a-nemzetkozi-jogban-es-az-igazsagszolgaltatasra-gyakorolt-hatasuk/

Fináczy Ernő: A középkori nevelés története. Budapest, Kir. Magyar Egyetemi Nyomda, 1926.

Frivaldszky János: Az emberi személy és annak méltósága jogfilozófiai perspektívában - különös tekintettel a jogalanyisághoz és az élethez való jog aktuális kérdéseire. Acta Humana, 2. (2014), 1. 7-74. Online: https://jak.ppke.hu/uploads/articles/498685/file/Acta\%20Humana\%202014_1\%2001\%20Frivaldszky\%20(1)\%20(3)\%20(1)\%20(1)\%20Copy.pdf

Frivaldszky János (szerk.): A jogfilozófia alapvető kérdései és elemei. Budapest, Szent István Társulat, 2013.

Gradvohl Edina: Az abortusz megítélése az antik világban. Müvelödés-, Tudomány-és Orvostörténeti Folyóirat, 6. (2015), 11. 1-11. Online: https://doi.org/10.17107/KH.2015.11.1-11

A gyermeknevelés „eretneke” és médiasztárja - száz éve született Benjamin Spock. Gondola, 2003. május 1. Online: https://gondola.hu/cikkek/23106-A_gyermekneveles_eretneke_es_mediasztarja___szaz_eve_szuletett_Benjamin_Spock.html

Hammurabi törvényei. (ford. dr. Kmoskó Mihály), Kolozsvár, Az Erdélyi Múzeum-Egyesület Jog- és Társadalomtudományi Szakosztálya, 1911. Online: http://epa.oszk.hu/eme/books/ b1_234480.pdf

Hollósi Hajnalka: Gyermekkép, gyermekvilág, gyermekfelfogás változásai pedagógiai megközelítésben. Iskolakultúra, 2. (2008). 92-103. Online: http://misc.bibl.u-szeged.hu/45530/1/iol_2008_ 001_092-103.pdf

Lang Tünde: Gyermekkitevés és abortusz a Római Birodalomban. Újkor, 2020. augusztus 2. Online: https://ujkor.hu/content/gyermekkiteves-es-abortusz-romai-birodalomban

Lux Ágnes: A gyermekjogi mozgalom fejlödése és az európai független gyermekjogi intézmények öszszehasonlitó perspektívában. Doktori (PhD-) értekezés. Budapest, Eötvös Loránd Tudományegyetem, 2018. Online: https://doi.org/10.15476/ELTE.2018.060

Péter Orsolya Márta: „Alimenta”. A családpolitika és a gyermekes családoknak nyújtott állami támogatások előképei a klasszikus Rómában. Publicationes Universitatis Miskolcinensis. Sectio Juridica et Politica 23/1. (2005), 91-124. Online: http://real.mtak.hu/80274/1/Alimenta.pdf

Portik Erzsébet Edit: Gyermeknevelés az ókori társadalmakban. Magiszter, 12. (2012), 2. 71-80.

Pukánszky Béla - Németh András: Neveléstörténet. Budapest, Nemzeti Tankönyvkiadó, 1996.

Pukánszky Béla: A gyermekkor története. Budapest, Műszaki Könyvkiadó, 2001.

Rousseau, Jean-Jacques: Emil vagy a nevelésröl. Budapest, Tankönyvkiadó, 1978.

Spock, Benjamin: Dr. Spock on Parenting: Sensible Advice from America's Most Trusted Child-Care Expert. New York, Simon \& Schuster, 1988.

Vajda Zsuzsanna - Pukánszky Béla: A gyermekkor története. Szöveggyűjtemény. Budapest, Eötvös József Kiadó, 1988. 